Research Articles

\title{
The Effect of Glutathione on Serum Malondialdehyde (MDA) Level in Retinopathy of Prematurity Rat Models
}

\author{
Puspita Kusuma Dewi $^{1 *}$, Maharani ${ }^{2}$, Riski Prihatningtias ${ }^{2}$, Liana Ekowati2, Arief Wildan ${ }^{2}$ \\ ${ }^{1}$ Department of Medical Biology and Biochemistry, Faculty of Medicine, Diponegoro University, \\ Semarang, Indonesia \\ ${ }^{2}$ Department of Ophthalmology, Faculty of Medicine, Diponegoro University, Semarang, Indonesia
}

\section{Article Info}

History

Received: 19 Nov 2020

Accepted: 26 Dec 2020

Available: 31 Dec 2020

\begin{abstract}
Background: Retinopathy of prematurity (ROP) is the leading cause of blindness in newborn babies worldwide. The benefit of anti-oxidant was investigated for ROP cases by assessing its effect on the oxidative stress of the tissues. Glutathione is a primary endogenous in human body and its supplementation has been discovered for its benefits towards some ocular diseases.

Objective: This study aims to understand the effect of glutathione on oxidative stress marker, serum Malondialdehyde (MDA), in ROP rat models.

Methods This was an experimental study with posttest only controlled group design. Sixteen Wistar rats that met our study criteria were divided into two groups, study group and control group. The study group were exposed to $95 \%$ oxygen for 4 hours / day followed by normoxic laboratory condition for 20 hours. Glutathione $1.5 \mathrm{mg}$ / day were injected intramuscularly to rats in study group. The control group was exposed to $95 \%$ oxygen followed by normoxic laboratory condition with the same manner, and did not received glutathione. This cycle was repeated for 14 days. Both groups were settled in a room temperature setting on days 15-22. Serum sample was collected from retroorbital vein. The malondialdehyde level was analyzed using MDA analyzer kit.

Results MDA level was found significantly higher in study group compared to control group (546.99 $\mathrm{ng} / \mathrm{ml} \mathrm{vs} 201.51 \mathrm{ng} / \mathrm{ml}$, respectively, p 0,001).

Conclusion Our study demonstrated a higher MDA levels in ROP rat models given glutathione injection compared to the control group.
\end{abstract}

Keywords Retinopathy of prematurity; glutathione; malondialdehyde. Permalink/ DOI: https://doi.org/10.14710/jbtr.v6i3.9414

\section{INTRODUCTION}

Retinopathy of prematurity (ROP) is a developmental retinal vascular disorder that affects prematurely born infants. Retinopathy of prematurity is the leading cause of blindness in new born babies worldwide. Prematurity, low birth weight, blood transfusion, sepsis, intraventricular hemorrhage, blue light therapy, mechanical ventilation therapy, and administration of high-pressure oxygen are some condition that increase the risk of developing ROP. ${ }^{1-4}$

\footnotetext{
*Corresponding author:

Email: puspita0602@gmail.com

(Puspita Kusuma Dewi)
}

Recent study has found that oxidative stress plays an important role in pathogenesis of ROP. Retina as one of body tissues that are sensitive to hypoxic and hiperoxic conditions will undergo oxidative stress due to high pressure oxygen exposure. This is characterized by imbalance of reactive oxygen species (ROS) and antioxidant levels in the body. ${ }^{2}$ Malondialdehyde (MDA) has been widely used as an oxidative stress biomarker. ${ }^{3-5}$ MDA levels in body tissues can indicate the occurring stress oxidative stress degree. ${ }^{5}$

The antiperoxidative effects of some anti-oxidant agents such as vitamin E, vitamin A, Lutein, superoxide dismutase (SOD) have been studied in ROP cases with conflicting results. Some benefits and the harmful side effects of the anti-oxidant have been reported. ${ }^{6}$ Thus, antiperoxidative effects of other antioxidant are much 
needed to be explored, particularly in ROP case. Glutathione (GSH) is the primary endogenous antioxidant in the body. Glutathione is formed naturally inside the body, but increased of free radicals production leads to inadequate availability of these antioxidant. ${ }^{6-8}$ Glutathione have been studied for some ocular disorders such as cataract and glaucoma. ${ }^{6,9}$ In this study investigated the effect of glutathione injection on MDA levels in rat models that exposed to high pressure oxygen (ROP rat models).

\section{MATERIALS AND METHODS}

This was an experimental study with post test only controlled group design. Breeding and intervention of animal was performed in Biology Laboratory, Faculty of Mathematics and Sciences, Universitas Negeri Semarang. The sample was 16 Wistar rats (1-7 days old), weighed 10-20 grams. All Wistar rats were given standard feeding and suckled directly from the mother. Management and treatment of experimental animals in this study has been approved by the Ethics Health Research Commission, Faculty of Medicine, Diponegoro University/ Kariadi Central Public Hospital, Semarang (No. 10/EC/H/FK-UNDIP/II/2019)

\section{Hyperoxic exposure}

A preliminary study was conducted to refine the hyperoxic exposure effect to the histological appearance of retina in rats. We found that the hyperoxic exposure induced higher amount of retinal neovascularization compare to the control group. ${ }^{10}$ In the current experiment, sixteen Wistar rats that met our study criteria were used. The rats were randomly divided into two groups, study group and control group. The study group rats were placed on animal box which $95 \%$ oxygen was continuously delivered at a flow rate 2.7 liters/minute. Rats were exposed to this hyperoxic condition for 4 hours / day, followed by normoxic laboratory condition for 20 hours. The control group was exposed to $95 \%$ oxygen exposure with similar administration manner for 4 hours / day followed by normoxic laboratory condition for 20 hours. This cycle was repeated for 14 days. Both groups were settled in a room temperature setting on days 15-22.

\section{Glutathione supplementation}

Glutathione $1.5 \mathrm{mg}$ intramuscular / day were injected to rats in study group for 14 days.

\section{Serum sampling and MDA level Analysis}

Serum sample was collected from retroorbital vein on day 23. The malondialdehyde level was analyzed using MDA analyser kit. MDA level analyzed using MDA analyzer kit and performed in GAKI Laboratory, Faculty of Medicine, Diponegoro University.

The obtained data were analyzed statistically using SPSS for windows version 19.0. Data normality test were done by Saphiro-Wilk test and the hypothesis was tested by unpaired $\mathrm{T}$ test.

\section{RESULTS}

Sixteen Wistar rats in both groups were alive on day 23 when the experiment terminated. The collected data was serum MDA level in both groups. Mean MDA level in control group was $201.51 \pm 62.55 \mathrm{ng} / \mathrm{ml}$, with minimum level $106.65 \mathrm{ng} / \mathrm{ml}$ and maximum level 326.60 $\mathrm{ng} / \mathrm{ml}$. Mean MDA level in study group was $546.99 \pm$ $118.38 \mathrm{ng} / \mathrm{ml}$, with minimum level $327.94 \mathrm{ng} / \mathrm{ml}$ and maximum level $707.92 \mathrm{ng} / \mathrm{ml}$ (Table 1).

All data were normally distributed based on statistical analysis using Saphiro wilk test. The analysis showed that MDA level of the study group was higher than control group, with $p$ value 0.001 (Table 2)

Table 1. MDA Level

\begin{tabular}{ccccc}
\hline Group & $\mathbf{n}$ & $\begin{array}{c}\text { Mean } \pm \text { SD } \\
(\mathbf{n g} / \mathbf{m l})\end{array}$ & $\begin{array}{c}\text { Minimum } \\
(\mathbf{n g} / \mathbf{m l})\end{array}$ & $\begin{array}{c}\text { Maksimum } \\
(\mathbf{n g} / \mathbf{m l})\end{array}$ \\
\hline Control & 8 & $\begin{array}{c}201.51 \pm \\
62.55\end{array}$ & 106.65 & 326.60 \\
& & $\begin{array}{c}546.99 \pm \\
118.38\end{array}$ & 378.94 & 707.92 \\
Study & 8 & & \\
\hline
\end{tabular}

Table 2. Unpaired T test results

\begin{tabular}{ccccc}
\hline Group & n & $\begin{array}{c}\text { Mean } \pm \text { SD } \\
(\mathbf{n g} / \mathbf{m l})\end{array}$ & $\begin{array}{c}\text { Median } \\
(\mathbf{n g} / \mathbf{m l})\end{array}$ & $\boldsymbol{p}$ \\
\hline Control & 8 & $201.51 \pm$ & 190.53 & 0.001 \\
& & 62.55 & & \\
Study & 8 & $\begin{array}{c}546.99 \pm \\
118.38\end{array}$ & 533.25 & \\
& & & \\
\hline
\end{tabular}

\section{DISCUSSION}

Studies about glutathione's protective effect on oxidative stress has been developed in several animal models such as myocardial injury, liver injury, renal ischemia, cataracts, and glaucoma animal models. ${ }^{9-14}$ This study used oxygen induced retinopathy (OIR) methods to assess the effect of glutathione in ROP rat models. Our study revealed that serum MDA level of Wistar rats exposed to oxygen is higher than serum MDA level of healthy rats obtained from the literature data. Healthy Wistar MDA level was in the range 78.5-97.3 $\mathrm{nmol} / \mathrm{mg}$ while MDA level of ROP rat models in this study were in the range $106.44-327.81 \mathrm{nmol} / \mathrm{mg} .{ }^{15}$ This is consistent with previous study that demonstrated an increase in MDA levels of retinopathy of prematurity babies. Premature babies has not ready to experience extra uterine life that contains high oxygen content. The use of high concentration oxygen therapy in premature babies worsen the oxidative stress that happened, characterized by increase of MDA level, both in serum and tissues. One of the tissues that experiencing developmental aberration due to complex oxidative stress process is retina. ${ }^{16-20}$

Analysis of this study showed MDA level in Wistar retinopathy of prematurity models injected with glutathione intramuscularly was higher than the control group (546.99 ng/ml vs $201.51 \mathrm{ng} / \mathrm{ml}$, respectively). This result was contradicting to some of previous studies about glutathione. Study about injection of glutathione in renal ischemia animals revealed a lower MDA levels in the treatment group compare to the control group (25.40 $\mathrm{nm} / \mathrm{mg}$ protein vs $37.40 \mathrm{~nm} / \mathrm{mg}$, respectively). ${ }^{11}$ Similarly to study about the effect of glutathione on rat with myocardial injury, obtained MDA levels in treatment group $(0.6 \mathrm{nmol} / \mathrm{mg})$ was lower than the control group $(0.7 \mathrm{nmol} / \mathrm{mg}) .{ }^{13}$ Our study result was also contradictive to study about another antioxidant, L- 
carnitine, that was tried out to ROP rat models. Lcarnitine has protective effect, characterized by decrease in MDA level from $24.44 \mathrm{nmol} / \mathrm{mg}$ to $13.86 \mathrm{nmol} / \mathrm{mg}^{3}$

It has widely known that oxidative status in human body is affected by the balance between free radicals agent and antioxidant that counter back. Imbalance leads to progressive damage of cell structure. Antioxidant supplementation helps body defensive system to fight back free radicals, especially ROS. On the other hand, ROS in normal level is doing its function, cell signaling and regulating redox. Free radicals escalation in the moderate amount can stimulates body immunity system and have protective effects in the body. ${ }^{12}$ Studies suggested to calculate endogenous antioxidant level in the body before administer synthetic antioxidant supplementation. Thus, there would be no antioxidant level excess in the body than could lead to antioxidant imbalance. Previous study reported there are some synthetic antioxidant that can be contradictory, known as pro-oxidant. Pro-oxidant is a compound that stimulates oxidative process in the body through the formation of singlet oxygen. ${ }^{21}$ Some of the theories mentioned above might become explanations regarding the high level of oxidative stress markers in antioxidant supplementation in this study. The dose of glutathione used in this study was likely too high to be injected into baby rat, thereby stimulating the oxidant-antioxidant imbalance. To date, there is no preceding study suggesting about injecting glutathione to baby rat even it is safe to administer glutathione for a full-grown rat. We suggest further research with adjusted dosage of glutathione.

\section{CONCLUSION}

Our study demonstrated a higher serum MDA levels in ROP rat models given glutathione injection compared to the control group. Further study about antiperoxidative effect with an adjusted dosage of glutathione are warranted

\section{REFERENCES}

1. Lueder G AS, Hered R, Karr D, Kodsi S. Pediatric ophthalmology and strabismus, Basic and Clinical Science Course. San Fransisco: The American Academy of Ophthalmology; 2017. p. 321.

2. Couroucli XI. Oxidative stress in the retina: implications for Retinopathy of Prematurity. Current Opinion in Toxicology. 2017.

3. Keles S, Caner I, Ates O, Cakici O, Saruhan F, Mumcu UY, et al. Protective effect of L-carnitine in a rat model of retinopathy of prematurity. Turkish Journal of medical sciences. 2014;44(3):471-5.

4. Edy Siswanto J, Sauer PJ. Retinopathy of prematurity in Indonesia: incidence and risk factors. Journal of neonatal-perinatal medicine. 2017;10(1):85-90.

5. Wang H. Anti-VEGF therapy in the management of retinopathy of prematurity: what we learn from representative animal models of oxygen-induced retinopathy. Eye and brain. 2016;8:81.

6. Giblin FJ. Glutathione: a vital lens antioxidant. Journal of Ocular Pharmacology and Therapeutics. 2000;16(2):121-35.
7. Sankar MJ SJ. Vitamin E supplementation for prevention of morbidity and mortality in preterm infants [internet]: WHO Reproductive Health Library; 2011 [updated August 2011; cited 2018 November 15].

8. Beharry KD, Valencia GB, Lazzaro DR, Aranda JV, editors. Pharmacologic interventions for the prevention and treatment of retinopathy of prematurity. Seminars in perinatology; 2016: Elsevier.

9. Dorfman AL. Oxygen Induced Retinopathy in the Neonatal Rat: The Effects of Age, Strain and Therapeutic Intervention on Retinal Structure and Function [dissertation]. Montreal: McGill University; 2010.

10. Tita E, Agung AP, Puspita KD. Gambaran vaskularisasi retina pasca pemberian oksigen konsentrasi tinggi (studi eksperimental ROP pada tikus wistar). Jurnal Kedokteran Diponegoro. 2018;7(4):1707-19

11. Ahmadvand $\mathrm{H}$, Babaeenezhad E, Nasri M, Jafaripour L, Khorramabadi RM. Glutathione ameliorates liver markers, oxidative stress and inflammatory indices in rats with renal ischemia reperfusion injury. Journal of Renal Injury Prevention. 2019;8(2):91-7.

12. Weschawalit S, Thongthip S, Phutrakool $P$, Asawanonda P. Glutathione and its antiaging and antimelanogenic effects. Clinical, cosmetic and investigational dermatology. 2017;10:147.

13. Nagar A. Protective effect of glutathione against isoproterenol induced myocardial injury in rats. Indian J Physiol Pharmacol. 2013;57(2):132-7.

14. Wang J, Chen Y, Gao N, Wang Y, Tian Y, Wu J, et al. Inhibitory effect of glutathione on oxidative liver injury induced by dengue virus serotype 2 infections in mice. PloS one. 2013;8(1):e55407.

15. Sutaryono S, Andasari SD, Hidayati N. Pengaruh Pemberian Campuran Bee Pollen, Rimpang Kencur, Kunyit dan Biji Pinang Terhadap Penurunan Kadar Malondialdehida (MDA) pada Tikus Wistar Pasca Paparan Streptozotocin. 2016.

16. Boyd K. What is Retinopathy of Prematurity (ROP)? [internet].2018 [updated April 28, 2018; cited 2018 November 13]. Available from: https://www.aao.org/eye-health/diseases/what-isretinopathy-prematurity.

17. Retinopathy of Prematurity - Asia Pacific [internet].2013 [updated November 2013; cited 2018 november 13]. Available from: https://www.aao.org/topic-detail/retinopathy-ofprematurity--asia-pacific.

18. Stuart A. Current ROP Therapies: How Laser and Anti-VEGF Compare 2014.

19. Garg U, Jain A, Singla P, Beri S, Garg R, Saili A. Free radical status in retinopathy of prematurity. Indian Journal of Clinical Biochemistry. 2012;27(2):196-9.

20. Lee JW, Davis JM. Future applications of antioxidants in premature infants. Current opinion in pediatrics. 2011;23(2):161.

21. Kim Y-W, Byzova TV. Oxidative stress in angiogenesis and vascular disease. Blood. 2014;123(5):625-31. 